\title{
New species of Gonomyia Meigen, 1818 (Diptera: Limoniidae) from Middle Asia
}

\author{
Новые виды Gonomyia Meigen, 1818 (Diptera: Limoniidae) \\ из Средней Азии
}

\author{
D.I. Gavryushin \\ А.И. Гаврюшин
}

\begin{abstract}
Zoological Museum, Moscow State University, Bol'shaya Nikitskaya 6, Moscow, 125009, Russia. E-mail: dmitry_gavryushin@yahoo.com Зоологический музей, Московский государственный университет, Большая Никитская ул., 6, Москва 125009 Россия
\end{abstract}

KEYWORDS: Diptera, Limoniidae, Gonomyia, Middle Asia, Kazakhstan, Tajikistan, taxonomy, description, new species

КЛЮЧЕВЫЕ СЛОВА: Diptera, Limoniidae, Gonomyia, Средняя Азия, Казахстан, Таджикистан, таксономия, описание, новый вид

ABSTRACT. Two new species of Gonomya (s.str.) Meigen, 1818 are described from Middle Asia, Gonomyia kiritschenkoi sp.n. from Tajikistan and Gonomyia grunini sp.n. from Kazakhstan. Descriptions of males and illustrations of male genitalia are provided.

РЕЗЮМЕ. ОПисаны два новых вида рода Gonomya (s.str.) Meigen, 1818 из Средней Азии, Gonomyia kiritschenkoi sp.n. из Таджикистана и Gonomyia grunini sp.n. из Казахстана. Даны описания самцов и иллюстрации гениталий.

\section{Introduction}

While studying short-palped crane-flies (Limoniidae) from the collection of the Zoological Institute of the Russian Academy of Sciences (St. Petersburg, Russia), two species new to science belonging to the nominative subgenus of the genus Gonomyia Meigen, 1818 (subfam. Chioneinae) were discovered. Gonomyia (s.str.) Meigen, 1818 is the second-largest subgenus of this genus of short-palped crane-flies (Limoniidae) with 189 taxa described worldwide so far, 45 species being Palaearctic in distribution [Oosterbroek, 2014]. The main diagnostic features of the subgenus are as follows (mostly after Savchenko [1989]): Rs with 3 branches reaching wing margin; at least 2 pairs of gonostyli; vein $S c$ long, vein $S c_{1}$ usually ending beyond the origin of $R s$; male hypopygium usually with gonocoxites having a large dorsolateral lobe; aedeagus and parameres usually asymmetrical, the latter appearing as sinuate to undulate spines.

\section{Material and methods}

The morphological terms used here mainly follow McAlpine [1981], venation is described mostly after
Alexander and Byers [1981]; descriptions of male genitalia mostly after Starý [2011]. Male genitalia were boiled in $10 \%$ solution of potassium hydroxide $(\mathrm{KOH})$ for 60 to $90 \mathrm{~s}$, neutralised by a $10 \%$ solution of acetic acid $\left(\mathrm{CH}_{3} \mathrm{COOH}\right)$, washed in water and then stored in glycerine. Dissected male genitalia were examined with a Nikon SMZ645 zoom stereomicroscope and then photographed using an eTREK DCM900 camera on MBI-1 microscope; images were processed with CombineZP software (Alan Hadley, http://www.hadleyweb. pwp.blueyonder.co.uk). Type material is deposited in the Zoological Institute of the Russian Academy of Sciences (ZIN).

\section{Species descriptions}

Gonomyia kiritschenkoi sp.n. Figs 1-6.

MATERIAL. Holotype, male (unique specimen), Tajikistan, Sughd province, right bank of Iskander Darya River near its source, Lake Iskanderkul, approx. $39.08^{\circ} \mathrm{N}, 678.38^{\circ} \mathrm{E}, 2200 \mathrm{~m}, 19$. VII.1947, A. Kiritschenko leg. (double-mounted on minuten pin to a piece of cardboard attached to insect pin, antennae and wings intact, all legs but two (right fore leg and right mid leg) missing; genitalia dissected by the author and placed in a sealed plastic tube with glycerine pinned with the specimen).

DIAGNOSIS. Medium-sized yellow-brown species with typical Gonomyia appearance. Body length and wing length ca. $6,5 \mathrm{~mm}$.

DESCRIPTION. Male. Head yellow, vertex mostly grey, rostrum yellow, palpi brownish. Antennae almost reaching the bases of wings if bent backwards, scape yellowish-brown, pedicel dark-brown, antennal flagellomeres fusiform proximally, elongate-cylindrical distally, brown with usual dense short hairs and sparce bristles, the longest of these bristles roughly equal in length to corresponding segments. 
Thorax with cervical sclerites brown; pronotum yellow with large brownish area dorsally; prescutum slightly pruinose, reddish-brown, widely margined with yellow, including prescutal pits, triangular posterior region after the suture also yellow; scutum slightly shining, reddish-brown with posterior angles of the lobes and wide median area between them yellow; scutellum slightly shining, yellow; mediotergite pruinose, brownish with yellow margins; pleurae yellow, with indistinct brownish areas. Halteres rather long, with stems yellow and knobs somewhat darker. Legs of moderate length, yellow, tips of tarsi darker, coxa and trochanters brighter orange-yellow.

Wings with membrane weakly tinged with yellow, veins yellow, very faint yellow stigma present. Venation usual for subgenus, vein $S c_{1}$ ending beyond the origin of $R s$, crossvein $m-c u$ slightly beyond the base of discal cell, vein $A_{2}$ sinuous distally.

Abdomen yellow, with a wide brownish stripe dorsally. Hypopygium (Figs 1-3) of moderate size, yellow. Tergite 9 transverse, obtrapezoid, proctiger narrowly sclerotised laterally, posterior angles with dense hairs, posterior margin with beak-like projection medially. Sternite 9 distally with wide trapezoid projection. Gonocoxites elongate-conical, dorsolateral lobes well-developed, almost reaching midlength of outer gonostyli, elongateoval, obtuse, with dense long hairs, similar but more sparce hairs on ventromesal margins of gonocoxites. Outer gonostyli as long as gonocoxites, at near third of its length curved both inwards in dorsal view and down in lateral aspect, conspicuously and deeply bifid, flattened laterally, the outer arm twice as long as the inner one, with blackened edge and numerous setae on both sides; the inner arm in the form of a short dark-pigmented blade. Inner gonostyli (Fig. 6) subtriangular in shape, comparatively small, inner part membraneous, rostrum short, somewhat tapered apically, with two strong setae at its tip; outer part produced into long and sharp hook which is curved and blackened apically. Two more stout spines originate from the base of inner gonostylus dorsally, the inner spine shorter and curved outwards, the outer spine the longest of the three (equal to dorsolateral lobe of gonocoxite) and curved inwards. Aedeagus (Fig. 4) rather stout, flattened laterally and strongly dilated at midlength, its apical third strongly curved so ventral subapical excision very deep and wide, no distinct projection proximal to it; apical portion of aedeagus well before its tip conspicuously extended blade-like upwards in lateral aspect. Parameres (Fig. 5) strongly asymmetrical, both as simple rods with acute apices and darkly pigmented tips, downcurved in lateral view, triangular appendages at its fused bases; left paramere much shorter, around one half the length of right paramere; right paramere more stout, apically at about one third of its length abruptly curved outwards in dorsal aspect.

Female unknown.

ETYMOLOGY. This species is named in honour of its collector, Alexander N. Kiritschenko (18841967), eminent Russian hemipterologist.
DISCUSSION. By the structure of male genitalia described here which is quite remarkable, this new species is very different from all other species known from the Palaearctic region. Some features quite close to shown above can be traced elsewhere, e.g. similarly bifid outer gonostyli in Gonomyia principalis Alexander, 1938 (China) [Alexander, 1938] or development of spines on inner gonostyli in Gonomyia hippocampi Stubbs and Geiger, 1993 (Europe) [Stubbs and Geiger, 1993], but other characters totally mismatch.

DISTRIBUTION. Tajikistan.

\section{Gonomyia grunini sp.n.}

Figs 7-10.

MATERIAL. Holotype, male, Kazakhstan, Karagandy region, Shet district, Bassaga env., approx. $47.95^{\circ} \mathrm{N}, 72.95^{\circ} \mathrm{E}, 800 \mathrm{~m}$, 22.VI.1959, K. Grunin leg. (mounted directly, pinned through thorax on insect pin, antennae and wings intact, 3 legs (both mid legs and left hind leg) missing; genitalia dissected by the author and placed in a sealed plastic tube with glycerine pinned with the specimen). Paratype, male, same data (mounted directly, pinned through thorax on insect pin, antennae and wings intact, 3 legs (both fore legs and left mid leg) missing; genitalia dissected by the author and placed in a sealed plastic tube with glycerine pinned with the specimen).

DIAGNOSIS. Medium-sized yellow-brown species with typical Gonomyia appearance, readily recognised by extremely long aedeagus (when dissecting genitalia, the author initially took it for some kind of straw or hair which stuck to hypopygium). Body length and wing length ca. $6 \mathrm{~mm}$.

DESCRIPTION. Male. Head yellow, rostrum yellow, palpi brownish. Antennae almost reaching the bases of wings if bent backwards, scape yellowish-brown, pedicel dark-brown, antennal flagellomeres fusiform proximally, elongate-cylindrical distally, brown with usual dense short hairs and sparce bristles, the longest of these bristles roughly equal in length to corresponding segments.

Thorax with cervical sclerites and pronotum yellow; prescutum slightly pruinose, brown, widely margined with yellow, including prescutal pits, triangular posterior region after the suture brownish-yellow; scutum brown with posterior angles of the lobes and wide median area between them yellow; scutellum slightly shining, brownish-yellow; mediotergite pruinose, brownish with wide yellow margins; pleurae yellow. Halteres rather long, uniformly obscure-yellow. Legs of moderate length, yellow, tips of tarsi darker, coxa and trochanters brighter orange-yellow, femora with apical areas (approximately one eighth of its length) dark-brown, tibia very narrowly dark-brown apically.

Wings narrow, with membrane weakly tinged with yellow, veins yellowish-brown, stigma absent. Venation in general similar to that of Gonomyia lobulata Savchenko, 1980 [Savchenko, 1980]; vein $S c$, ending shortly beyond the origin of $R s$, tip of vein $R_{1}$ opposite the point of furcation of $R_{2+3}$, the latter with a point of origin common with $R_{4+5}$ and $r-m ; R_{4+5}$ in alignment with $R s$; crossvein $r-m$ long (approximately one half 

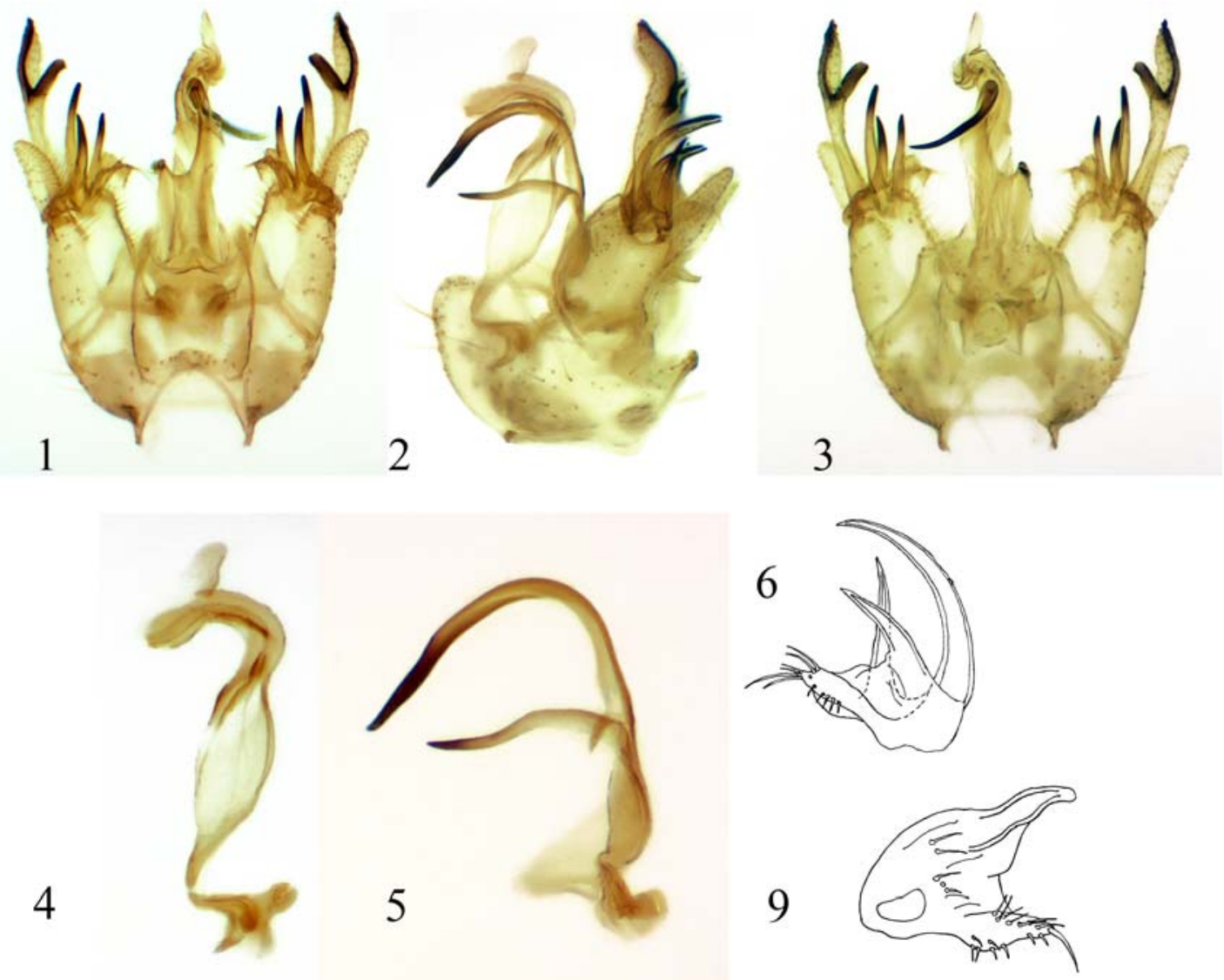

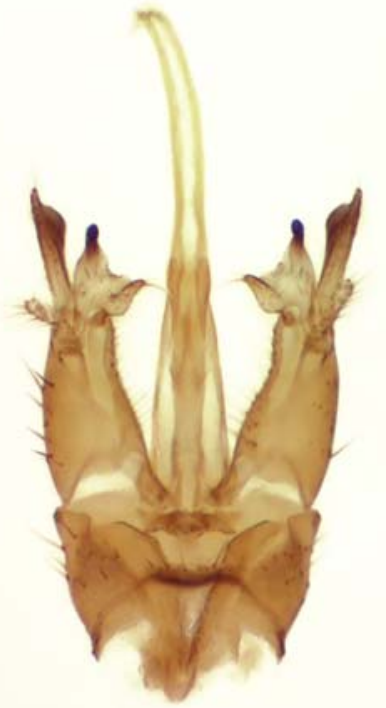

7

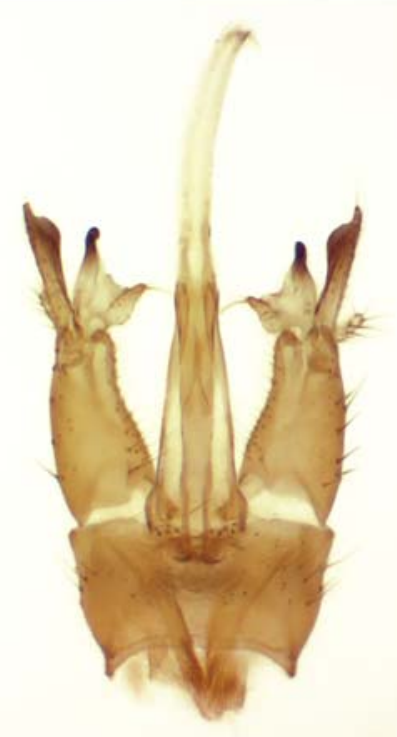

8

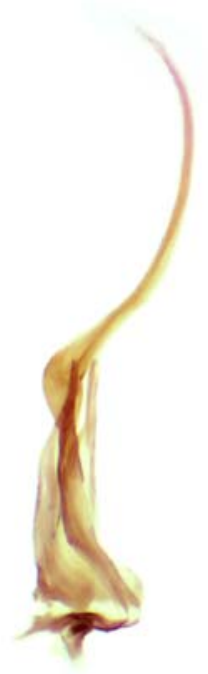

10

Figs 1-10 (not on same scale). Gonomyia kiritschenkoi sp.n., holotype $\sigma^{7}$ (1-6) and Gomonyia grunini sp.n., holotype $\sigma^{7}$ (7-10): 1 hypopygium, dorsal view; 2 - same lateral view; 3 - same, ventral view; 4 - aedeagus, lateral view; 5 - parameres, lateral view; 6 left inner gonostylus, ventral view; 7 - hypopygium, dorsal view; 8 - same, ventral view; 9 - left inner gonostylus, dorsal view; 10 aedeagus with parameres, lateral view.

Рис. 1-10 (масштаб разный). Gonomyia kiritschenkoi sp.n., голотип О7 (1-6) и Goтопуia grunini sp.n., голотип Оフ (7-10): 1 гипопигий, вид сверху; 2 - то же, вид сбоку; 3 - то же, вид снизу; 4 - эдеагус, вид сбоку; 5 - парамеры, вид сбоку; 6 - левый внутренний гоностиль, вид снизу; 7 - гипопигий, вид сверху; 8 - то же, вид снизу; 9 - левый внутренний гоностиль, вид сверху; 10 - эдеагус и парамеры, вид сбоку. 
the length of $R_{2+3}$ ) and curved; discal cell elongatepentagonal, widened distally; crossvein $m-c u$ one third of its length beyond the base of discal cell.

Abdomen yellow, with a wide brownish stripe dorsally. Hypopygium (Figs 7-8) of moderate size, yellow. Tergite 9 transverse, almost twice as wide as long, medially with deep trapezoid excision. Sternite 9 simple. Gonocoxites elongate-conical, dorsolateral lobes rather short, around one half the length of outer gonostyli, oval, obtuse, with long hairs, similar hairs on ventromesal margins of gonocoxites which become shorter distally. Outer gonostyli slightly longer than one half the length of gonocoxites, strongly pigmented apically, in the form of thick rods with fingerlike apices and big rounded ventromesal protuberances subapically. Inner gonostyli (Fig. 9) triangular in shape, three fourths the length of outer gonostyli, inner part pale, with short beak-like projection tipped with one strong seta; outer part simple in structure, with single finger-like projection darkly pigmented at apex. Aedeagus (Fig. 10) remarkably long, twice longer than gonocoxites (even longer in paratype, approximately 2.3 times longer than gonocoxites), strongly flattened dorsoventrally, with acute outer angles at apex and conspicuous knot-like swelling at near midlength, apical half of aedeagus strongly arched and gradually becoming thinner. Parameres symmetrical, weakly pigmented and short, closely adjoining the basal half of aedeagus, conical in shape and tapering apically to long finger-like tips.

Female unknown.

ETYMOLOGY. This species is named after its collector, Konstantin Ya. Grunin (1911-1981), well-known Russian dipterologist.

DISTRIBUTION. Kazakhstan.

DISCUSSION. Extremely long aedeagus together with weakly developed parameres closely adjoining aedeagus is the combination of diagnostic characters which can not be found in any of described Palaearctic species of Gonomyia (s.str.).
ACKNOWLEDGEMENTS. I wish to express my sincere gratitude to Dr. Nikolai M. Paramonov (Zoological Institute of the Russian Academy of Sciences, St. Petersburg, Russia) for the loan of material and Drs. Andrey L. Ozerov and Nikita E. Vikhrev (both Zoological Museum of Moscow University, Moscow, Russia) for continuing encouragement and support.

ERRATUM. In my previous article [Gavryushin D.I. 2012. Rhipidia Meigen, 1818 (Diptera: Limoniidae): a new species from India and a new record for the Palaearctic region // Russian Entomol. J. Vol. 21. No. 1. P.101-106], in descriptions of tergites 9 of Rhipidia scopifera (p. 103, right column, line $18 \mathrm{ff}$.) and Rhipidia schwarzi (p. 106, left column, line 11 ff.) anterior margin of the tergite actually means its posterior margin, and vice versa.

\section{References}

Alexander C.P. 1938. New or little-known Tipulidae from eastern Asia (Diptera). XXXVIII // Philippine Journal of Science. Vol.66. P.309-342.

Alexander C.P., Byers G.W. 1981. Tipulidae // J.F. McAlpine et al. (eds.). Manual of Nearctic Diptera 1. Research Branch, Agriculture Canada, Ottawa, Monograph No.27. P.153-190.

McAlpine J.F. 1981. Morphology and terminology - adults. In J.F. McAlpine et al. (eds.). Manual of Nearctic Diptera 1. Research Branch, Agriculture Canada, Ottawa, Monograph No.27. P.9-63.

Oosterbroek P. 2014. Catalogue of the Craneflies of the World ((Diptera, Tipuloidea: Pediciidae, Limoniidae, Cylindrotomidae, Tipulidae), online at: http://nlbif.eti.uva.nl/ccw/ (last accessed April 02, 2014).

Savchenko E.N. 1980. [Two new species of Gonomyia (Diptera, Limoniidae) from Sovjet Middle Asia] // Vestnik Zoologii. No.3. P.36-41 [in Russian].

Savchenko E.N. 1989. [Limoniidae fauna of the USSR]. Kiev: Akad. Nauk Ukrainian SSR. 377 p. [in Russian].

Starý J. 2011. Gonomyia (Gonomyia) lucidula and allies (Diptera: Limoniidae). // Entomologica Fennica. Vol.21. P.232-242.

Stubbs A.E., Geiger W. 1993. Gonomyia (s. str.) hippocampi sp. n., a new european Eriopterinae (Diptera, Limoniidae) // Mitteilungen der Schweizerischen Entomologischen Gesellschaft. Vol.66. P.435-437. 